\title{
Divulgación
}

\section{Cambios en hábitos y rutinas diarias de personas afectadas por la catástrofe hídrica de la ciudad de Santa Fe.}

RECIBIDO: 25/06/2011

ACEPTADO: 15/09/2011

\section{Bofelli, M. • Boggio, C. • Chiapessoni, D. • Demichelis, M. • Demiryi, M. de los M. • Heit, M. del C.}

\begin{abstract}
Universidad Nacional del Litoral. Facultad de Bioquímica y Ciencias
Biológicas. Escuela Superior de Sanidad Dr. Ramón Carrillo.

Ciudad Universitaria, Paraje el Pozo-CC 242-S3000ZAA-Santa Fe.

Argentina

Tel.: (0342) 4575209 Interno 105. E-mail: avenida@arnetbiz.com.ar
\end{abstract}

\begin{abstract}
RESUMEN: La inundación de Santa Fe ocurrida en el año 2003, generó la inquietud de investigar la dimensión ocupacional de esta catástrofe. Los objetivos de este trabajo fueron: (1) analizar los cambios de rutinas y hábitos; los procesos de interrupción y adaptación ocupacional;
\end{abstract}

(2) construir indicadores de necesidades y (3) detectar los soportes más efectivos para la recuperación ocupacional. El diseño combinó aportes de la etnografía y la fenomenología. Participaron 54 personas pertenecientes a los 9 barrios más afectados, los que expresaban la diversidad de las características del fenómeno estudiado. Las edades oscilaron entre 22 y 86 años. Narrativas ocupacionales, entrevistas en profundidad e historias de vida fueron los instrumentos utilizados para la recolección de los datos.
Los resultados indicaron tres momentos: pre-catástrofe, catástrofe y post-catástrofe, cada uno con peculiaridades respecto a los cambios ocupacionales. Los significados de la ocupación y las pérdidas, su potencialidad y sobrecarga, orquestación ocupacional y participación social, fueron algunos de los hallazgos más significativos. PALABRAS CLAVE: catástrofe; hábitos; rutina; terapia ocupacional

SUMARY: Routine life habits changes in the populatios affected by flood catrastophe in the city of Santa Fe.

The flood that ocurred in Santa Fe in 2003 led us to investigate the occupational dimensions of the catastrophe. The aims of this study were: (1) to analize the changes in routine life habits and interruption and adaptation of occupational processes; (2) 
to build up indicators of bare necessities and; (3) to detect the most useful affective support for occupational recover. The design of the study included elements from the ethnography and phenomenology. Fifty-four persons from the 9 most affected neighborhoods participated in the study; they expressed the diverse characteristics of the phenomenon. Their ages ranged between 22 and 86 years. Occupational narratives, in-depth interviews and life stories were the instruments used to collect data. The results indicated three relevant stages: pre-catastrophe, catastrophe and post-catastrophe; each one with peculiar occupational changes. The meaning of occupation and loss, their potentiality and overloads, the occupational instrumentation and social participation were some of the most significant findings.

KEYWORDS: catastrophe; habits; occupational therapy; routine

\section{Introducción}

Las inundaciones en la provincia de Santa $\mathrm{Fe}$, representan una de las mayores catástrofes de la Argentina en los últimos años. En el 2003 se afectaron de manera directa 130.000 personas, produciendo la transformación de toda la ciudad, a raíz del desborde del río Salado, que bordea el cordón oeste y por la existencia de obras inconclusas. En el 2007 fueron 25.000 personas y más de 60 localidades del interior de la provincia quienes sufrieron la inundación, a causa de la combinación de precipitaciones extremas y la falta de obras.

Estos hechos marcaron y cambiaron la vida de muchos pobladores y barrios de la ciudad, produciendo pérdidas en vidas, viviendas, instalaciones, producción, trabajo, infraestructura y daños en la salud, la educación, las fuentes laborales y la identidad de personas, familias, barrios y comunidades; efectos que perduran en el tiempo.

La vivencia directa durante la inundación del 2003 y la participación en las tareas de emergencia y reconstrucción, motivaron la decisión de constituir un grupo de investigación de terapia ocupacional.
Esta dolorosa experiencia ha puesto en evidencia la crisis de ciertos conocimientos académicos y la falta de formación específica en el tema, en la mayoría de las disciplinas.

Entendiendo que las ciencias y sus respectivas disciplinas cumplen con funciones cognitivas pero también políticas, el equipo se propuso contribuir al debate y al aporte de soluciones en relación al tema. Por considerar que resulta ineludible y urgente que los terapeutas ocupacionales incorporemos a nuestra agenda, los temas que actualmente afectan a las poblaciones más desprotegidas como el hambre, la pobreza, la exclusión, las políticas públicas y los derechos humanos y que tomemos posicionamientos acorde al compromiso ético y moral que nos cabe.

La problemática de los desastres y catástrofes viene siendo estudiada de manera creciente desde diferentes disciplinas. La declaración de las Naciones Unidas de los años 1990/1999, como Decenio Internacional para la reducción de desastres y el establecimiento de la Secretaría Permanente "Estrategia Internacional para la reducción 